\title{
D. Żołądź-Strzelczyk, K. Kabacińska-Łuczak, Codzienność dziecięca opisana stowem i obrazem. Życie dziecka na ziemiach polskich od XVI do XVIII wieku, Wydawnictwo DiG, Warszawa 2012, ss. 192
}

Prezentowana książka jest pozycją niezwykłą na rynku wydawniczym, a to ze względu na jej naukowy charakter i niespotykane bogactwo ilustracji, doskonale obrazujących treść. Książka Doroty Żołądź-Strzelczyk i Katarzyny Kabacińskiej-Łuczak składa się ze wstępu, sześciu rozdziałów oraz zakończenia, bibliografii, wykazu fotografii oraz indeksów: osób i miejscowości. Poszczególne rozdziały omawiają inne aspekty życia dzieci na ziemiach polskich w okresie od XVI do XVIII w., a mianowicie: narodziny i początek życia, sprawy rodzinne, ubiór, sprzęty domowe, przeznaczone dla dzieci, zabawy i edukację oraz w końcu troskę o dzieci.

Autorki rozpoczynają pracę od przybliżenia czytelnikowi przedmiotu badań i ukazania charakterystyki materiałów źródłowych, stawiając tezę, że równoległa analiza przekazów ikonograficznych i pisanych, wraz z pozostałościami materialnymi, pozwolą na uzyskanie przynajmniej zbliżonego obrazu życia dziecka w Rzeczypospolitej wybranego okresu. Następnie przedstawiono stan badań nad szeroko rozumianą problematyką dziecięca, uwzględniając jednak także problematykę metodologiczną, związaną ze źródłami ikonograficznymi. Te bowiem zostały zadeklarowane jako podstawowy typ przekazów wykorzystanych przy opracowywaniu książki. Źródła ikonograficzne narzuciły jednocześnie jako dominującą problematykę „materialnej” strony życia dzieci, włączając w to ubiór dziecięcy czy przedmioty związane z życiem codziennym. Pozwoliły zaś z drugiej strony ukazać inne, trudno uchwytne strony egzystencji dzieci, jak życie w rodzinie, zabawy oraz edukacja (chociaż, jak zauważyły Autorki, informacje dostarczane w tym przypadku są mniej wyraźne).

Sprawy narodzin dziecka rozpoczyna omówienie elementów ikonograficznych, występujących w sztuce, a związanych z tą tematyką. Analizie poddano tutaj przede wszystkim różne przedstawienia narodzin Maryi, na podstawie których wyprowadzane są wnioski na temat warunków zapewnianych podczas narodzin dzieci, opieki nad położnicami i noworodkami i wszelakich zabiegów czynionych przy okazji porodu czy okresu wczesnoniemowlęcego. Liczne przedstawienia tego rodzaju, jak zauważono, dają możliwość ukazania zachodzących w tej materii zmian. Dodatkowo, pozwalają na zapoznanie się z takimi przedmiotami, jak: naczynia do kąpieli, pieluchy, ręczniki, kołyska, pościel, powijaki. W dalszej części rozdziału dokładnie omówione zostały zabiegi kąpieli i krępowania niemowląt powijakami, miejsce do spania, karmienie dzieci, a na końcu chrzest.

Drugi rozdział książki został poświęcony sprawom rodzinnym. Problematykę otwiera zagadnienie liczebności rodziny, co przedstawiono na podstawie badań demograficznych i analizy materiałów ikonograficznych, co oczywiście zostało w odpowiedni sposób zobrazowane. Dodatkowo, dokładnie omówiono sposób prezentacji osób na obrazach. Kolejne zagadnienie, a mianowicie relacje w rodzinie rozpoczyna przedstawienie poglądów teoretyków wychowania na tę sprawę: Mikołaja Reja, Andrzeja Frycza Modrzewskiego, 
Erazma Glicznera, Sebastiana Petrycego z Pilzna i Andrzeja Maksymiliana Fredry. Ukazawszy postulaty, Autorki dokonały analizy źródeł epistolograficznych, testamentów, pamiętników i diariuszy, aby ukazać faktyczne oddziaływanie rodziny na dzieci i sposób sprawowania nad nimi opieki.

Tematem trzeciego rozdziału są ubiory dziecięce, omówione, ze względu na bogactwo materiałów źródłowych, bardzo obszernie. Narrację, jak poprzednio, rozpoczynają wskazówki pisarzy staropolskich: Reja, Glicznera i Petrycego, po czym następuje opis poszczególnych elementów stroju dziecięcego. Odrębnie zaprezentowano stroje dziewczęce i chłopięce, uwzględniając zarówno stroje narodowe, jak i związane z modą obcą. Autorki wyraźnie uzależniły rodzaj noszonego ubioru od zajmowanej pozycji społecznej. Dużo miejsca poświęciły omówieniu strojów szlacheckich, a także tych, noszonych na dworze królewskim. Widoczna jest jednak dysproporcja w odniesieniu do ubiorów stanu mieszczańskiego, nie wspominając już o chłopskim, o którym wspomniano tylko w kilku słowach. Oczywiście tłumaczyć to można nielicznymi przekazami źródłowymi na ten temat, jednakowoż można by się w tym przypadku wspomóc źródłami pisanymi, co z powodzeniem uczyniono w przypadku innych zagadnień, poruszanych w książce.

W dalszej części pracy omówione zostały różnego rodzaju sprzęty domowe, przeznaczone dla dzieci. Wprowadzeniem w problematykę jest charakterystyka miejsca przeznaczonego dla nich - w tym przypadku przede wszystkim na podstawie zróżnicowanych źródeł pisanych. Kolejne zagadnienia, które zostały poruszone, to: łóżka i pościele, małe krzesła, chodziki, sprzęty związane z utrzymaniem higieny i na koniec naczynia do karmienia dzieci.

„Zabawa i edukacja wypełniały znaczną część życia dziecka” (s. 124), jak pisały Autorki i dlatego też wyodrębniono kolejny rozdział, poświęcony tej tematyce. Najpierw zarysowany został ogólny szkic historii zabaw na podstawie średniowiecznych i nowożytnych źródeł polskich i europejskich, po czym zaprezentowano konkretne przykłady materiałów ikonograficznych. Kolejnym, obszernie omówionym, zagadnieniem, z którym możemy się zapoznać, to zabawki, przeznaczone dla dzieci w różnym wieku. Warto podkreślić, że w celu egzemplifikacji wyodrębniono z materiałów źródłowych wiele interesujących przedstawień przedmiotów o przeznaczeniu ludycznym czy edukacyjnym. Nauce zresztą poświęcono osobną część w tym rozdziale, najpierw omawiając edukację domową, a następnie szkolną. Także w tym wypadku udało się odnaleźć ciekawe przedstawienia graficzne, ukazujące nauczanie dzieci w domu, moment oddawania syna do szkoły czy lekcje szkolne. Można tutaj zapoznać się także z wyobrażeniem nauki w krakowskiej szkole prezentek, przeznaczonej dla dziewcząt (1793 r.).

Ostatni rozdział poświęcony został trosce o dzieci, zwłaszcza w sytuacji choroby, wypadku i w obliczu śmierci dziecka. Na podstawie licznych materiałów źródłowych (księgi cudów i obrazy wotywne) Autorki stwierdzaja, że ,ani choroba, ani śmierć nie była rodzicom obojętna, gotowi byli wiele uczynić, aby dziecko wróciło do zdrowia czy w przypadku śmierci - do życia" (s. 146). Przedstawione zostały również religijne zabiegi o pomoc w przypadku bezdzietności oraz przy porodzie.

Podsumowując informacje o prezentowanej książce, trzeba zauważyć, że jest to pozycja, jakiej z pewnością brakowało w polskiej literaturze historycznej. Co więcej, inte- 
resujące przedstawienie materiału i bogata egzemplifikacja graficzna czynią z niej pracę, która spotyka się z zainteresowaniem nie tylko historyków, ale też pozostałych czytelników. Podkreślenia wymaga fakt, że wszystkie problemy badawcze opracowane zostały na solidnej bazie źródłowej, dobrze udokumentowanej, w dodatku bez zarzucania czytelnika nadmierną liczbą faktów. Jest to efekt wieloletniej pracy badawczej Autorek, które nie szczędziły sił, by przeprowadzona kwerenda była jak najpełniejsza.

Michat Nowicki

\section{A. Fijalkowski, Tradycja i nowatorstwo w Orbis sensualium pictus Jana Amo- sa Komeńskiego, Wydawnictwa Uniwersytetu Warszawskiego, Warszawa 2012, ss. 410}

W polskiej literaturze historyczno-oświatowej dorobek J. A. Komeńskiego był przedmiotem kilkudziesięciu rozpraw i artykułów. Już w 1874 r. ukazało się pierwsze samodzielne opracowania A. Bądzkiewicza, dotyczące systemu wychowania Komeńskiego i jego znaczenia dla rozwoju pedagogiki. W okresie międzywojennym ukazały się prace A. Danysza i K. Banszela, a po wojnie monograficzne opracowania poświęcili mu Ł. Kurdybacha, S. Helsztyński, B. Suchodolski i T. Bieńkowski. Różnorodne aspekty działalności Komeńskiego omawiano w licznych artykułach i na konferencjach naukowych, których pokłosie wydawane było drukiem ${ }^{1}$. Do licznego grona badaczy dołączył w ostatnim czasie także A. Fijałkowski.

A. Fijałkowski już od kilku lat prowadzi systematyczne badania nad dorobkiem Komeńskiego, których wyniki publikowała na łamach czasopism naukowych w języku polskim angielskim i niemieckim. Był też autorem rocznicowej wystawy poświeconej pierwszemu wydaniu Orbis sensualium pictus, która prezentowana była w kilku polskich miastach i z którą wiązało się wydanie autorskiego opracowania Orbis pictus - Świat malowany Jana Amosa Komeńskiego (Warszawa 2008). Prezentowana praca z pewnością stanowić będzie ważną pozycję w krytycznym rozpoznaniu dorobku czeskiego pedagoga, ze względu na solidność badawczą, dużą erudycję Autora i wykorzystanie wielu nowych źródeł, także pośrednio dotyczących badanego problemu.

Praca składa się z dziewięciu problemowych rozdziałów, ułożonych w sposób logiczny, z których pierwszych sześć prezentuje drogę do powstania dzieła. Autor zawarł w nich wnikliwą analizę źródeł, z których Komeński czerpał inspiracje do swojej pracy, jak też prezentację ówczesnych środowisk naukowych w kręgu których przebywał. Analiza dorobku ówczesnych pedagogów dydaktyków, pozwoliło Autorowi wskazać grupę uczonych, którzy byli prekursorami w tworzeniu obrazkowych podręczników i ,żywego alfabetu”. Komeński znał dokładnie ich dorobek i często go powielał lub uzupełniał i rozwi-

\footnotetext{
1 Zob. bibliografię prac J. A. Komeńskiego do 2008 oprac. Przez B. Budkiewicz, P. Michalską http:// wmbp.edu.pl/uploads/File/zestawienia_bibliograficzne/Jan_Amos_Komenski.htm
} 